tax, increasing improvement in the structure, interpretation and administration of the tax, difficulties with it should be far less in the future than they have been in the past when it has been a new tax operating under war conditions. What advantage in the convenience of the sales tax compares with the advantage of the income tax in ceasing to accrue when there is no net income?

This very consideration, that the income tax diminishes in yield in bad years, of course emphasizes the need of the government to have at all times sources of revenue other than income taxes. Such sources can, however, be maintained as they have been without resort to the wholly inclusive general sales tax. So far as sales taxes are needed, and they will be needed for some time, use can continue to be made of taxes levied upon the sales of selected articles not of prime necessity and levied at one stage of the process only so as to avoid any cumulative effect. $^{6}$

That objections to the general sales tax are much more than academic is shown by the rejection of the tax by the United States Chamber of Commerce in the recent referendum to its constituent local chambers of commerce throughout the United States; by the Tax Committee of the National Association of Credit Men; and notably by the rejection of it, after careful consideration and investigation, by the Tax Committee of the National Industrial Conference Board.

\footnotetext{
${ }^{6}$ For a discussion of the methods of replacing revenue lost through the abolition of the excess profits tax and reduction of surtaxes, see the report of the Tax Committee of the National In. dustrial Conference Board, Special Report No. 18, December, 1920. See also in such report the discussion of the general sales tax and full statement of the reasons which induced a report against this tax by a committee unusually representative of industry.
}

\title{
The Tariff Policy of the United States As a Creditor Nation
}

\author{
By D. A. Forward \\ Assistant Cashier, The National City Bank of New York
}

\begin{abstract}
THE problem of providing the 1 United States Government with sufficient revenue to meet its fiscal requirements is one which, of necessity, is demanding the thoughtful attention of those charged at the present time with that responsibility. With the loss of excise taxes due to prohibition and the increasing diminution in the returns from the chief sources of revenue under existing laws -the income and excess profits taxesit is not surprising that this country should turn to the tariff as a possible means of raising additional revenue. Indeed, it is a repetition of history that
\end{abstract}

import duties should be called upon to help meet the revenue burdens occasioned by war and, furthermore, that an upward revision of the tariff schedules should be strongly agitated in a period of unbalanced domestic markets by those who fear the importation on an extensive scale of commodities produced abroad under supposedly more advantageous conditions.

Current estimates indicate that something in excess of four billion dollars will constitute the minimum ordinary fiscal needs of the government for the next two years, exclusive of the retirement of the certificates of 
indebtedness outstanding, practically a quarter of which will be required to pay the interest charges on government securities issued in conjunction with the war and the carrying costs of the Treasury Department's floating indebtedness. Of the estimated total given, the Underwood Tariff-which carries the lowest average rate of duty of any enactment since the Civil War-has proved itself capable of producing a minimum of $\$ 182,759,000$, in 1918 , and a maximum of $\$ 323,537$,000 , in the year 1920 .

A study of the principal sources of federal revenue by decades since the beginning of the nineteenth century indicates that customs supplied from seventy to ninety per cent of the revenue received from 1800 to 1863 . With the rapid rise in the national debt at that time, customs, for a matter of about six years, yielded only from twenty-five to thirty-five per cent of the total revenue, following which, up through the period of the PayneAldrich Act, the returns from the tariff fluctuated from one-third to onehalf of the total receipts. The balance accrued with the exception of about ten per cent derived from miscellaneous sources, from excise taxes principally on distilled liquors and tobaccos.

Prior to our entrance into the war the Underwood Tariff appears to have accounted for substantially a third of the government's fiscal requirements. If the pre-war federal requirements be multiplied by six, an estimated deficit faced for the next two years of from one and one-half to two billion dollars, and the returns from liquor taxes practically eliminated, there can be little doubt that the government can well afford to consider carefully the revenue possibilities of the tariff, but with a full appreciation of the fact that the income and excess profits taxes, as they now exist, are decidedly more important than the tariff from a revenue standpoint.

Acknowledging that additional revenue will be needed-a fact hardly subject to refutation on the basis of probable reductions in the federal budget of consequence in the near future - and that the tariff might be expected to produce a substantial part of it, it might appear in the light of past experience that the requests from domestic industry for a higher protective tariff could and should be quite fully satisfied. To do so, however, under existing domestic and international conditions, would place this country in an anomalous and, in some respects, a disadvantageous position from both a fiscal and trade standpoint. The objections which might be raised to such a procedure under the circumstances would be relatively unimportant, perhaps, so long as the fundamental principles of equitable taxation were not violated, although many of the arguments formerly advanced in favor of a protective tariff have lost much of their original force due to the growth of the productive facilities and the consumptive power of the United States.

The successful application of the income and excess profits taxes demands a substantial volume of profitable business which will yield a return comparing favorably with the amount on the basis of which the revenue estimates and levies were formulated. To those who understand the elements and economic forces which govern the continuity and stability of industry and trade, it is quite clear that the present economic situation in this country has been precipitated, in a large measure, by an increasing inability to dispose of its excess production through export channels and concurrently receive reimbursement therefor which will permit an uninter- 
rupted turnover of its productive cycles. And it is to be remembered in this connection that the expansion which the productive capacity of the country underwent during the war period unquestionably requires the stabilizing support of permanent foreign markets if maximum production is to be approximated, if full employment is given to labor on wage scales even relatively higher than those existing in the pre-war period, and if the normally anticipated amount of revenue is to accrue to the government from business and individual incomes.

The crux of the situation from a trade standpoint is that the position of the United States as a creditor nation is such that necessity, rather than a mutually beneficial exchange of commodities and services, is being substituted more and more as the primary inducement for purchasing the products this country has to offer. The fact that a trade balance exists in its favor might or might not be important from a tariff standpoint, depending on the purposes of the duties levied. England, for example, had an unfavorable trade balance for years and yet followed a policy of confining the import duties imposed solely to the purposes of revenue. Her ability to assume such an attitude is to be explained in part by the volume of her "invisible exports" which according to estimates of the British Board of Trade aggregated $£ 640,000,000$ in the year 1920 ; while Sir George Paish is authority for the estimate that the net investment of British capital abroad in 1914 amounted to approximately $\$ 20,000,000,000$. However, from the standpoint of present tariff legislation, particularly when further protection is being advocated, the amount of the entire international balance in favor of this country has an important bear- ing on the subject, if due consideration is to be given to the liquidation of existing foreign indebtedness to the United States, and to the ability of present foreign debtors to safely incur additional obligations through further purchases of its surplus products. Upon that consumptive ability, domestic industry and the Treasury Department seem to need to rely, the former for a maximum amount of profitable business and the latter, both directly and indirectly, for revenue.

During the abnormal conditions of the past several years it is estimated by some authorities that the position of this country has changed from a debtor nation to that of a creditor with an aggregate balance in its favor of perhaps as much as eighteen billion dollars. With a marked decrease in the total value of the invisible exports formerly available to them, with the practical exhaustion of international banking credit, and with gold stocks a hopelessly insufficient and quite inadvisable means of trade settlement, but two other channels remain through which foreign debtors can effect payment,- the shipment of goods and the sale of securities. Under these circumstances, and giving due regard to the fact that foreign countries face the payment of a current floating indebtedness of from $\$ 3,500,000,000$ to $\$ 4,000$,000,000 in addition to an annual interest charge of nearly $\$ 500,000,000$ on loans extended by our government, the proposal to raise a high tariff barrier around this country assumes more importance than that of merely satisfying the protectionist. The government, from a revenue viewpoint, has a selfish interest in assisting, in every way compatible with the safety of our domestic industries, the creation of international trade balances which will make it possible for the annual interest charge on its foreign loans to be 
liquidated. It would appear relevant to remark that this amount totals more than twice the average annual sum realized from the Underwood Tariff. Even if balances created by increased imports were not sufficient for a time to leave a surplus to be applied on the interest indebtedness, presumably they would serve at least as an offset for exports in which the government likewise is interested to the extent of insuring a degree of domestic prosperity sufficient to produce a satisfactory return from internal taxes. Furthermore, it is patent that the yield from any tariff is dependent upon the volume of dutiable imports.

But it would be short-sighted indeed to enact any tariff law which did not provide, equally well, protection where it was justified, revenue where it could be secured without placing an unjust tax on manufacturers dependent upon imported raw materials, and a basic principle building towards the ultimate payment of foreign indebtedness. The tariff law needed at present would combine the principle of a tariff for revenue with that of minimum protection where essential, with the emphasis placed upon the former. The inter-dependency of interests, domestic and foreign, must be given proper weight if the democratic principle is to be observed of enacting legislation from which will accrue the greatest benefit to the largest number. Presumably, the realization of such a principle rests upon the maximum possible volume of trade with a minimum burden to the ultimate consumer.

In considering the community of interests which should exist, a general indictment can not well be made of the motives of those whose natural interests lead them to advocate a protective tariff for the industries of their constituents, for, all things being equal, any legislation which increases the earning power, productive capacity, and stability of any domestic industry should result theoretically to the advantage of the immediate communities concerned and hence indirectly to the nation as a whole. It is such individual consideration and the "swapping" of support on the different schedules, however, which have carried protection much further than the point to which in certain instances there might have been a reasonable claim. The difficulty in the theory arises that "all things are not equal," a circumstance of which fair cognizance frequently is not taken, due to selfish and political considerations. It is a moot question how far protection should be given to any industry if, by so doing, it is placed in a position to keep out foreign competition that normally would provide one of the principal offsets against which other producers could ship their surplus and be assured of the margin of profit necessary in many cases to successful operation. In this connection it may be of interest to recall that this country recently has had a noteworthy example of the extent to which it considered its economic welfare dependent on the operation of any given industry, large though it might be, in the abolition of the manufacturing plants and distributing agencies of the brewery and liquor interests.

It seems to be conceded that the industries and those producing exportable foodstuffs and raw materials in the United States, as a whole, are in a preferred competitive position. It can not be stated conclusively, however, that no protection whatever is needed, for it is conceivable that some of the domestic markets could be seriously handicapped by the inflow of a large volume of goods produced at lower costs abroad, since American buyers can purchase more advan- 
tageously in certain lines in foreign countries than at home, due to the enhanced value of the American dollar with respect to local currencies. The only protection offered to the United States by the depreciated exchanges is to be found in those cases where raw materials must be secured, in the main, from this country for manufacturing purposes and then re-exported in the form of a manufactured article. Recent instances are available in the field of finished cotton goods showing that even under such circumstances, and in spite of a protective tariff, foreign manufacturers have under-sold American producers of similar products. Incidentally, this example will serve, possibly as well as any other, to illustrate the well-recognized fact that the final incidence of a protective tariff falls upon the ultimate consumer through an increased price.

An analysis of what are perhaps the latest reliable comparative statistics showing the relative value of the output per labor unit in the United States and in the United Kingdom-our principal foreign customer and trade rival-rather clearly indicates that the higher wages enjoyed by labor in this country probably have been made possible more through the development and use of labor-saving machinery and through large-scale production than by a protective tariff, as has been quite commonly asserted in the past. While it is readily granted that statistics serve better as indices than as final proof of a given conclusion, and admitting the difficulty under existing conditions of securing reliable data which might serve as a basis for levying duties that would tend to equalize costs, the British Census of Production of 1907 and the last American Census of Production of 1909 , make possible startling comparisons of relative efficiency. An examination of twenty-six representative industries including boots and shoes, cardboard boxes, butter and cheese, cement, clothing, cocoa, chocolate and confectionery, cotton goods, clocks and watches, cutlery and tools, gloves, hosiery, finished leather, paints, paper, printing, silk, soap and candles, etc., shows that American industries produce from approximately two to three times as much per year per unit of labor, in the valuation of commodities manufactured on the basis of wholesale selling prices, as do corresponding English industries. These figures are secured by dividing the production per year by the number of wage-earners engaged in each given industry. The same tables indicate that almost invariably America's great superiority in production per wage-earner per year is accomplished by a similarly marked superiority in horse power employed for each thousand workers. The following are given as typical illustrations:

\begin{tabular}{|c|c|c|c|c|c|}
\hline \multicolumn{6}{|c|}{ Clothina } \\
\hline & $\begin{array}{l}\text { Produc- } \\
\text { tion per } \\
\text { year }\end{array}$ & $\begin{array}{c}\text { No. of } \\
\text { wage- } \\
\text { earners }\end{array}$ & $\begin{array}{c}\text { H. P. } \\
\text { employed }\end{array}$ & $\begin{array}{l}\text { H. P. per } \\
1000 \text { wage- } \\
\text { earners }\end{array}$ & $\begin{array}{l}\text { Value of produc- } \\
\text { tion per wage- } \\
\text { earner per year }\end{array}$ \\
\hline United Kingdom . . . . . . . . & $£ 62,169,000$ & 392,084 & 17,837 & 45 & $£ 158$ \\
\hline United States........... & $£ 190,566,000$ & 393,439 & 65,019 & 165 & $£ 484$ \\
\hline \multicolumn{6}{|c|}{ Boots and Shoes } \\
\hline & $\begin{array}{l}\text { Produc- } \\
\text { tion per } \\
\text { year }\end{array}$ & $\begin{array}{l}\text { No. of } \\
\text { wage- } \\
\text { earners }\end{array}$ & $\begin{array}{c}\text { H. P. } \\
\text { employed }\end{array}$ & $\begin{array}{l}\text { H. P. per } \\
1000 \text { wage- } \\
\text { earners }\end{array}$ & $\begin{array}{l}\text { Value of produc- } \\
\text { tion per wage } \\
\text { earner per year }\end{array}$ \\
\hline United Kingdom......... & $£ 20,095,000$ & 117,565 & 20,171 & 172 & $£ 171$ \\
\hline United States..... & $£ 102,359,000$ & 198,297 & 96,302 & 486 & $£ 516$ \\
\hline
\end{tabular}


As an example of the extractive industries, it is also of interest to note that in the year 1911 the number of tons of coal produced per annum per person employed in England was two hundred and sixty while in the United States it was six hundred and thirteen; the average selling price of coal per ton at the mouth of the mine in the same year, at a par of exchange, was approximately $\$ 1.97$ per ton for Great Britain, and $\$ 1.42$ per ton in the United States, in spite of the fact that higher wages were paid to the miner in the latter country. The relative advantage in manufacturing costs to a United States producer using steam power is obvious. What current statistics would indicate is not known but, generally speaking, recent difficulties between the miners in England and the government over the matter of wages and production would lead to the belief that a present comparison would prove even more unfavorable to England.

In further analyzing the whole question of comparative costs, it seems to be quite generally agreed that the war introduced a more or less uniformly higher world wage scale and higher standard of living, and that the effect on manufacturing costs was quite as marked and permanent in many of the foreign countries as it has been in the United States. If that viewpoint is correct and on the basis of the comparative figures just given, the conclusion would seem to be that the American producer in most instances can afford, for other reasons, to forego the enactment of a tariff to equalize costs of production, at the moment, or at least until the whole question can be adjusted upon a scientific basis of the facts as they now exist. Furthermore, if the theory of equalizing costs is pertinent, under present conditions it might be in order to beg the question to the extent of asking why, with the exchanges in favor of buying abroad, the figures of the Department of Commerce continue to show large trade balances in favor of this country, the most recent (January, 1921) placing the exports for the first month of the year at $\$ 655,000$,000 while imports were only $\$ 209,000$,000 , the smallest total for any month since February, 1918.

Relative to German competition, it should be borne in mind that in addition to a demoralized social structure Germany's industries must face large internal export taxes in addition to burdens imposed by the indemnity terms. In view of these handicaps and her depreciated exchanges, which play an important part in depriving her of many necessary raw materials, it would appear the part of enlightened selfishness not to subject her exports to this country to any unnecessary tariff if the ultimate payment of the international balance in our favor is considered dependent, to any appreciable extent, on the proceeds to be received by the Allied governments from a war indemnity.

South American exports to the United States, to quite a degree, are tropical and hence largely non-competitive in character. Like the Far Eastern nations, France, Italy and the other European countries consuming American products, the depreciated exchange position of South American countries requires that their imports must reach this country in larger volumes if the increased exports enjoyed in the past few years are to continue. If a tariff has any appreciable virtue, under such circumstances, its revenue possibilities, directly and indirectly, should seemingly be given paramount consideration.

The demands on the part of the farmers and other raw material producers for protection are interesting because they appear to be based 
largely upon false economic principles. If production in those directions were less than the amount domestic markets normally absorb, their arguments would be entitled to a more sympathetic hearing. On the contrary, the price of wheat, cotton, or any other commodity produced in excess of domestic demand is established in the final analysis in the markets of the world-liverpool in the case of wheat -by the marginal exportable surplus. In other words, if a farmer raises ten thousand bushels of wheat and there is a domestic consumptive demand for but nine thousand bushels, it is the price obtainable in the export market for his surplus of one thousand bushels that tends to fix the price for his whole crop. For that reason foreign trade is important in fixing prices, to a much larger degree than the small proportion it bears to domestic trade. By diverting the world's supply of wheat, produced outside of the United States, more directly to Liverpool, by means of a protective tariff, a tendency might even be encouraged to lower the price domestically. With no basic or "pegged" price the ultimate return to the farmer undoubtedly would be governed by the export price irrespective of any import duty imposed.

But even presuming that the price conceivably should be higher for some reason under a tariff, it is a politicalsocial question of some importance whether a primary necessity of life should be protected by a tariff, the burden of which would fall on the masses. This class of producers might more profitably direct their attention, it would seem, toward advocating the elimination of excessive duties on manufactured articles into which their raw materials go. Their efforts in that direction not only would help to sustain the export demand for their own products and benefit the general situation, but also would make the returned manufactured articles available to themselves at lower prices.

If the tariff is to be rebuilt with a view to securing the maximum revenue possible, due regard must be given to its relation to the income taxes and a firm foundation should be laid for future foreign trade with a minimum of protection given to those certain few essential industries which can present particular claims of an indisputable character for tariff consideration. The amount of duty to be levied on each commodity would require individual analysis, but the general policy might well be to impose a tariff designed to secure as much as the traffic would bear without materially decreasing the unit volume brought in or placing manufacturers dependent upon imports in a disadvantageous competitive position. It is quite possible that many or most of the three hundred and sixty-three articles appearing on the free list of the Underwood Tariff should carry import duties for revenue purposes. In any event under the program suggested, sugar, wool, coffee, tea, rubber, furs, hides, silk, cocoa, vegetable oils, spices, hemp, flax, long staple cotton, nitrates, potash and other minerals imported through necessity, tropical fruits, hard-wood lumbers, and other largely non-competing raw products would be among the commodities taxed; likewise perfumes, diamonds, cutlery, tobaccos, silk manufactured goods, china and fine glassware, and other articles of the luxury class would be included. In the case of dye-stuffs, and perhaps a few classes of manufactured goods, where industries have been established in a large way with the aid of a tariff and the question of the immobility of labor enters into the situation, if some protection were accorded temporarily, the exception made would have the virtue 
at least of yielding additional revenue, pending a readjustment of such industries which would place them in a position, unprotected, to compete in the markets of the world on an equal basis.

The tariffs being instituted or revised upwards by many foreign countries of late, offer an opportunity for the United States to show business sagacity and statesmanship of the first order by refusing to retaliate, at least for the time being. To retaliate would only complicate the situation and place the country in an even less favorable position for securing payment of its foreign accounts and for providing future markets for its exportable surplus. The losses sustained during the past two years by exporters in this country ought to offer sufficient proof that a sale of commodities for which no payment, or only partial payment, is made leads to embarrassment or ruin in foreign as well as domestic trade. The foreign tariffs in most instances are being levied on non-essentials, as no government can hope to stand which compels a discouraged citizenship to pay an unnecessary tax upon products essential to a country's economic well-being. If in addition some revenue is raised through tariffs, the country benefited is to that extent in a better position to liquidate its foreign obligations. In that, the United States should have a genuine interest, unless it prefers to tax its citizens indefinitely to pay the coupons of the liberty bonds offsetting its loans to foreign governments. Furthermore, it is perhaps quite conceivable that a creditor nation of influence will be in a position, if necessary, to ask and receive relief for any of its industries which are subject to unjust discrimination with respect to tariffs imposed on the same commodities imported from other countries.

The adoption of a policy of nonretaliation might lead quite naturally to the ultimate solution of the tariff problem which, undoubtedly, is to be found in the negotiation of special trade treaties, either between nations or through a centralized agency made up of the nations of the world, based upon the principle of equality of treatment. The impossibility of establishing reliable comparative values at present and international political complication, however, require the postponement of that method of solution until world conditions have become sufficiently stabilized to permit analysis. Confronted with such a situation and facing a deficit larger than the total pre-war federal budget, the interests of the nation at large seem to lead to a tariff designed primarily to provide revenue, and to aid rather than hinder its foreign trade. 